\title{
EKSISTENSI KETETAPAN MPR/S DALAM HIERARKI PERATURAN PERUNDANG-UNDANGAN DI INDONESIA
}

\section{THE EXISTENCE OF MPR/S PROVISION IN HIERARCHY OF LAWS AND REGULATIONS IN INDONESIA}

\author{
M. Saoki Oktava \\ Magister Ilmu Hukum Universitas Mataram \\ Email :m.saokioktava@gmail.com \\ Naskah diterima : 20/03/2017; revisi : 26/03/2017; disetujui : 27/04/2017
}

\begin{abstract}
Before UUD 1945 Amendment, MPR/S Provision is a legal product of MPR Institution which was the highest state institution. It affects the existence of product assessment issued and regulatory in nature (Regeling), which affects its implication as it becoming a law. The enactment of MPR/S Decree at Law No. 10 Year 2004 about Establishment of Legislation is because of to maintain consistency in the laws reference which has function to regulate called "regulation". This is to ensure so that there will be no more a question about the term "decision" which has the nature to set. It makes the enactment of $M P R / S$ doesn't exist in hierarchy of Laws. Reenactment of MPR/S in the Laws Hierarchy according to Law No. 12 Year 2011 about the Establishment of Legislation as a means to give a Legal Foundation of the enactment of $M P R / S$ which has the nature to set (regaling) which has still in effect, also as a means to strengthen the laws which based on the enactment MPR/S. The Institution which has the right to verify the enactment is regulated on MPR RI Decree No. II / MPR / 2000 Article 5, which state to verify the Laws against Constitution and MPR Decree, but MPR RI Decree No. III/MPR/2000 is redacted and replaced by MPR RI Decree No. I/MPR/20003. But According to principle of "contrariusactus", $M P R$ has the right to reevaluate and redact the Decree of $M P R / S$ which is the result of its own law.
\end{abstract}

Keyword: MPR/S Provision, Hierarcy Of Law

Abstrak

Sebelum Amandemen UUD 1945 Ketetapan MPR/S merupakan produk Hukum dari Lembaga MPR yang pernah menjadi lembaga Tertinggi Negara, sehingga berimplikasi terhadap eksistensi dari produk Ketetapan yang dikeluarkan dan bersifat mengatur (regeling) yang membawa implikasi terhadap keberlakuannya sebagai peraturan perundang-undangan. Dikeluarkanya Ketetapan MPR/S pada UU No. 10 Tahun 2004 Tentang Pembentukan Peraturan Perundang-undangan pertimbangannya adalah untuk menjaga konsistensi penyebutan peraturan perundang-undangan yang bersifat mengatur digunakan istilah "Peraturan". Hal ini dimaksudkan agar tidak lagi terjadi atau timbul pertanyaan mengenai istilah "Keputusan" yang bersifat mengatur ataupun yang bersifat penetapan. Sehingga Ketetapan MPR/S tidak tercantum dalam hierarki Peraturan Perundangundangan. Dicantumkannya kembali Ketetapan MPR/S di dalam hierarki peraturan perundangundangan menurut Undang-undang No. 12 Tahun 2011 Tentang Pembentukan Peraturan Perundang-Undangan, sebagai wujud untuk memberikan jaminan kepastian hukum terhadap Ketetapan MPR/S yang bersifat mengatur (regeling) yang masih berlaku, serta sebagai wujud untuk menguatkan Undang-undang yang berlandaskan pada ketetapan MPR/S. Lembaga yang berwenang menguji Ketetapan MPR/S pernah diatur pada Ketetapan MPR RI No. III/MPR/2000 Pasal 5 yaitu menguji Undang-undang terhadap UUD dan Ketetapan MPR, namun ketetapan MPR RI No. III/MPR/2000 telah dicabut dengan Ketetapan MPR RI No. I/MPR/2003. Namun berdasarkan asas "contrarius actus", MPR berwenang untuk menilai dan mencabut Ketetapan MPR/S yang merupakan produk hukumnya sendiri.

Kata Kunci : Ketetapan MPR/S, Hierarki Peraturan Perundang-Undangan 


\section{PENDAHULUAN}

Sebelum Amandemen Undang-Undang Dasar 1945, Negara Republik Indonesia menganut sistem supremasi Majelis Permusyawaratan Rakyat (MPR). Oleh karena itu kedaulatan berada ditangan MPR yang merupakan Lembaga Tertinggi Negara dan membawahi Lembaga lainnya seperti Lembaga Legislatif (DPR) maupun Eksekutif (Presiden).

Pada Tahun 1966 MPRS mengeluarkan Ketetapan MPRS No. XX/MPRS/1966, yang mengatur tata urutan hierarki peraturan perundang-undangan. Ketetapan MPRS No. XX/MPRS/1966 adalah sebagai berikut : ${ }^{1}$

1. UUD 1945

2. Ketetapan MPRS

3. UU/Peraturan pemerintah Pengganti Undang-Undang

4. Peraturan Pemerintah

5. Keputusan Presiden

6. Peraturan-Peraturan pelaksanaanlainnya seperti :

\section{Peraturan Menteri}

Instruksi Menteri, dan lain-lainnya.

Dari uraian di atas, apabila peraturan yang ada di bawah bertentangan dengan aturan yang ada di atas, maka aturan yang ada di bawah harus di cabut karena kekuatan hukum (rechtskraft) peraturan yang lebih tinggi dapat mengalahkan suatu peraturan yang lebih rendah.

Pada Tahun 2000 MPR mengeluarkan Ketetapan MPR No. III/MPR/2000 Tentang Sumber Hukum dan Tata Urutan Peraturan Perundang-Undangan, Ketetapan MPR No. XX/MPRS/1966 dicabut dan dinyatakan

${ }^{1}$ Sirajuddin, Fatkhurohman, dan Zulkarnain, Legislatif Draftin, Pelembagaan Metode Parsitipatif Dalam Pembentukan Pembentukan Peraturan Perundang-Undangan, (Malang : Setara Press, 2015). Hal. 47 tidak berlaku lagi. Oleh karena itu Ketetapan MPR No. III/MPR/2000 Pasal 2 yaitu:

Tata urutan peraturan Perundangundangan merupakan pedoman dalam pembuatan aturan hukum di bawahnya. ${ }^{2}$

Tata urutan peraturan perundangundangan republik Indonesia adalah :

1. UUD 1945

2. Ketetapan MPR

3. Undang-Undang

4. Peraturan Pemerintah Pengganti UU (Perppu)

5. Peraturan Pemerintah

6. Keputusan Presiden

7. Peraturan daerah.

Berlakunya Ketetapan MPR No. III/ MPR/2000 yang menggantikan Ketetapan No. XX/MPRS/1966 tentu menimbulkan persoalan, persoalannya adalah perbedaan kedudukan dari UU dengan Perppu, karena antara UU dan Perppu haruslah sama derajad atau kedudukannya.

Berdasarkan Ketetapan MPR RI No. I/ MPR/2003 yang merupakan dasar hukum dari terbentuknya UU No. 10 Tahun 2004 Tentang Pembentukan Peraturan Perundang-undangan, secara otomatis Ketetapan MPR/III/MPR/2000 tidak berlaku lagi. Namun pada UU No. 10 Tahun 2004 dapat di lihat Ketetapan MPR/S di hapuskan dari tata urutan hierarki peraturan perundang-undangan dalam Pasal 7 yaitu :

Ayat (1) Jenis dan Hierarki peraturan perundang-undangan adalah sebagai berikut : ${ }^{3}$

${ }^{2}$ Indonesia, Ketetapan Majelis Permusyawaratan Rakyat Sementara Republik Indonesia Nomor. III/ MPR/2000 Tentang Sumber Hukum dan Tata Urutan Peraturan Perundang-Undangan. Pasal. 2

${ }^{3}$ Indonesia, Undang-undang No. 10 Tahun 2004 Tentang Pembentukan Peraturan Perundang-undangan, 
M. Saoki Oktava|Eksistensi Ketetapan MPR/S Dalam Hierarki Peraturan Perundang-Undangan.........
a. Undang-Undang Dasar Negara Republik Indonesia Tahun 1945;
b. Undang-Undang/Peraturan Pemerin- tah Pengganti Undang-Undang;
c. Peraturan Pemerintahan;
d. Peraturan Presiden;
e. Peraturan Daerah.

Pada UU tersebut mengembalikan kedudukan Perppu setara dengan UU, sehingga ketika terjadi situasi genting maka Perppu dapat menggantikan UU. Akan tetapi persoalan baru kembai muncul dengan keluarnya ketetapan MPR/S sebagai jenis peraturan perundang-undangan menimbulkan berbagai pandangan.

Penghapusan Ketetapan MPR/S dari tata urutan peraturan perundang-undangan dinilai tepat, karena menurut Hamid S. Attamimi, Ketetapan MPR/S tidak dapat dikategorikan sebagai peraturan perundangundangan. ${ }^{4}$

Berhubungan dengan berlakunya UU No. 10 Tahun 2004 yang tidak mengatur Ketetapan MPR/S, ternyata menimbulkan pro dan kontra sehingga melalui UU No. 12 Tahun 2011 Tentang Pembentukan Peraturan Perundang-Undangan menggantikan keberlakuan dari UU No. 10 Tahun 2004. Pada UU No. 12 Tahun 2011, pembentuk UU mencantumkan kembali Ketetapan MPR/S sebagaimana Menurut Pasal 7 yaitu:

Ayat (1) Jenishierarkiperaturanperundangundangan terdiri atas : ${ }^{5}$

a. UUD RI Tahun 1945;

b. Ketetapan Majelis Permusyawaratan Rakyat;

c. UU atau Peraturan Pemerintah Pengganti Undang-Undang;

Pasal 7 Ayat (1).

${ }^{4}$ Ni'matul Huda, Hukum Tata Negara Indonesia. Ke 9 (Jakarta : Raja Grafindo Persada, 2014) Hal. 63

${ }^{5}$ Indonesia, Undang-Undang No. 12 Tahun 2011 Tentang Pembentukan Peraturan Perundang-undangan. Pasal 7 Ayat (1) d. Peraturan Pemerintah;

e. Peraturan Presiden;

f. Peraturan Daerah Provinsi;

g.Peraturan Daerah KabupatenatauKota.

Berlakunya UU yang baru (UU No. 12 Tahun 2011 Tentang Pembentukan Peraturan Perundang-undangan), tentunya materi muatannya tidak boleh bertentangan dengan aturan yang berada di atasnya. Apabila UU bertentangan dengan UUD 1945, Maka pengujiannya dilakukan oleh MK, begitu pula peraturan perundang-undangan di bawah UU, apabila bertentangan, pengujiannya dilakukan di MA. Hal tersebut dapat dilihat pada UU No. 12 Tahun 2011 pada Pasal 9 Ayat (1) dan Ayat (2). Namun, ada yang menarik untuk dicermati, yakni tidak adanya aturan yang mengatur tentang lembaga yang menguji Ketetapan MPR yang dianggap bertentangan dengan UUD 1945. Sehingga hal ini menimbulkan problem maupun kebingungan di masyarakat akibat dari kekosongan hukum yang terjadi di dalam ketentuan tersebut.

Berdasarkan uraian dari latar belakang, maka permasalahannya sebagai berikut: 1). Mengapa Ketetapan MPR/S di keluarkan dan dicantumkan kembali dalam hierarki peraturan perundang-undangan di Indonesia? Dan 2). Lembaga manakah yang berwenang menguji Ketetapan MPR/S?

Berdasarkan identifikasi masalah yang telah diuraikan, maka tulisan ini masuk dalam ranah penelitian hukum normatif. Untuk itu tulisan ini mempergunakan penelitian yuridis normatif.6 Pendekatan yang digunakan dalam penelitian ini yaitu:

a. Pendekatan Perundang-undangan (statute approach);

b. Pendekatan Konsep (Conseptual Approach);

c. Pendekatan Sejarah (historicalapproach).

${ }^{6}$ Zainal Arifin Hoesein, "Pembentukan Hukum Dalam Perspektif Pembaharuan Hukum", Jurnal Rechtsvinding, Media pembaharuan Hukum, Vol. 1 No. 3 (Desember 2012). Hal. 313 


\section{PEMBAHASAN}

Teori yang digunakan sebagai instumen mengkaji permasalahan dalam penelitian ini yaitu (1) Teori Negara Hukum Pancasila; (2) Teori Norma Hukum; dan (3) Teori Hierarki Norma Hukum.

\section{Teori Negara Hukum Pancasila}

Melihat jauh ke belakang, ide dasar mengenaikonsepnegarahukumIndonesia sebagaimana dinyatakan secara tegas dalam Undang-Undang Dasar 1945, tentu saja tidak dapat dipisahkan dari keberadaanPancasilasebagaidasarnegara dan sumber dari segala sumber hukum dan jiwa bangsa Indonesia. Dengan kata lain, sebagaimana telah dikatakan dalam bagiansebelumnyadapatdikatakanbahwa Pancasila menjiwai seluruh kehidupan negara hukum Indonesia. Dikatakan demikian karena Pancasila merupakan filsafat bangsa Indonesia dan filsafat itu merupakan pemikiran yang meliputi "de zin van wereld en leven" (makna dari dunia dan kehidupan). Demikian halnya denganfilsafatPancasila, filsafatPancasila telah diterima dan diakui sebagai filsafat bangsaIndonesiasekarangyangtidakperlu dibuktikan lagi kebenarannya. Maka dari itu, segala kegiatan dan tindakan dalam pembangunan negara dan masyarakat Indonesia harus berpangkal pada Pancasila. Dalam hukum, pendidikan, ekonomi, kesenian, kenegaraan dan pokoknya di semua bidang. ${ }^{7}$

\section{Teori Norma Hukum}

Dilihat dari perspektif suatu norma, normajuga dapat dibedakan antara norma yang umum (Algemeen) dan norma individual(Individueel), sertayangabstrakdan yang kongkrit. Pembedaan antara umumindividual didasarkan pada mereka yang terkena aturan norma tersebut. Jika di tu-

${ }^{7}$ I Ketut Adi Purnama, Transparansi Penyidikan dalam Kerangka Sistem Peradilan Pidana Untuk Membangun Kepercayaan Masyarakat Terhadap Polri, Disertasi, Universitas Katolik Parahyangan, 2011., Hal. 161. jukan kepada orang-orang atau sekelompok orang tertentu maka tergolong norma yangindividual, danjikaditujukankepada orang atau sekelompok orang yang tidak tertentu maka tergolong norma umum. Perbedaan yang abstrak dan kongkrit di dasarkan padahalyang diaturpada norma tersebut. Jika yang di atur peristiwa-peristiwa tertentu maka termasuk norma yang kongkrit.Peraturanperundang-undangan seyogyanya mengandung norma hukum yangumumabstrakatausekurang-kurangnya yang umum kongrit. ${ }^{8}$

\section{Teori Hierarki Norma Hukum}

Membahas mengenai jenis dan hierarki peraturan perundang-undangan, pasti tidak terlepas mengenai Teori Stuffenbou karya Hans Kelsen. Di dalam ajaran tersebut, Hans Kelsen berpendapat bahwa norma hukum itu berjenjangjenjang dan berlapis-lapis dalam suatu susunan hirarkis, dimana norma yang di bawahberlaku, sumber, danberdasar pada norma di atasnya, demikian seterusnya hingga sampai akhirnya regresus ini berhenti pada suatu norma yang tertinggi (Grondnorm). (Maria Farida, 1998:8). ${ }^{9}$

Teori Jenjang Norma dari Hans Kelsen terilhami pandangan teoritis yang dikembangkan oleh Adolf Melker, Teori Dua Wajah Norma Hukum (Das Doppelte Rechtsantlitz) dari AdolfMelker menyatakan bahwa suatu norma hukum memiliki dua wajah. Pada satu wajah ke atas, suatu norma hukum bersumber dan berdasar pada norma hukum di atasnya. Akan tetapi pada wajah lainnya, norma hukum tersebut sekaligus pula menjadi

8 Rosjidi Ranggawidjaja, Pengantar Ilmu Perundang-Undangan Indonesia, Cetakan Ke. 1. (Bandung : Mandar Maju 1998). Hal. 25-26

${ }_{9}$ Nur Amin Solikhah, "Problematika Hukum Undang-Undang No. 42 Tahun 1999 Tentang Jaminan Fidusia Terkait Dengan Peraturan Menteri Keuangan Republik Indonesia No. 130/MPK. 010/2012”. Jurnal Repertorium, ISSN : 2355-2646, Edisi 3 Januari-Juni 2015, Hal. 11 
sumber bagi norma hukum yang berada di bawahnya. ${ }^{10}$

Lihat bagan di bawah ini :

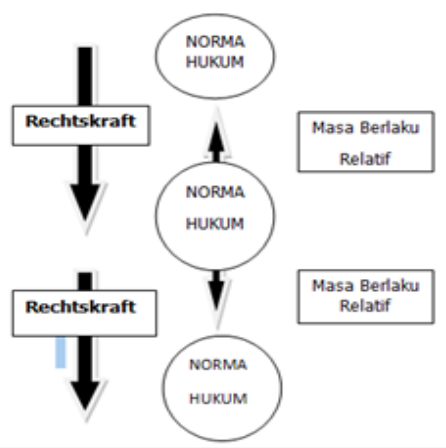

Bagan : Teori Dua Wajah Hukum (Das doppetle rechtsantlitz) ${ }^{11}$

Hans Nawiasky mengelompokan normahukumdalamsuatuNegaramenjadi empat kelompok, yaitu : ${ }^{12}$

Kelompok I Segara (Statfundamentalnorm)

Kelompok II : Aturan Dasar/Pokok

Negara (Staatsgrundgesetz)

Kelom pok II : Und ang - Un dang Formal (Formell Gesetz).

Kelompok IV: Aturan Pelaksana dan aturan otonom (Verodnung \& Auto Nome Satzung).

4. Pengujian Peraturan Perundang-undangan

Dalamprakteknya,dikenaladanyatiga macamnormahukumyangdapatdiujiatau yang biasa disebut sebagai norm control mechanism. Ketiga-tiganya sama-sama merupakan bentuk norma hukum sebagai hasil dari proses pengambilan keputusan hukum, yaitu : (i) keputusan normatif yang berisi dan bersifat pengaturan (regeling), (ii) keputusan normatif yang berisidanbersifatpenetapanadministratif

\footnotetext{
${ }^{10}$ Aziz Samsudin, Proses \& Teknik Penyusunan Undang-Undang, Edisi Kedua Cetakan Ke. 1(Jakarta :Sinar Grafika 2013). Hal. 21

${ }^{11}$ Ibid. Hal 22

${ }^{12}$ Ibid. Hal. 23
}

(beschikking), dan(iii)keputusannormatif yangberisidanbersifatpenghakimanyang biasa disebut vonis. ${ }^{13}$

A. Ketetapan MPR/S di Keluarkan dan dicantumkan Kembali Ke dalam Hierarki Peraturan Perundang-undangan di Indonesia

\section{Sejarah Undang-Undang Dasar dan Periode Masa berlakunya}

Secara historis, sejak Proklamasi 17 Agustus 1945 hingga saat ini, dalam sejarah ketatanegaraan Indonesia Pernah berlaku tiga macam Undang-Undang Dasar (Konstitusi) dalam empat beriode, yaitu sebagai berikut : ${ }^{14}$

1. Undang-Undang Dasar 1945, yang berlakuantaraTanggal18Agustus 1945 sampai dengan 27 Desember 1949.

2. Konstitusi Republik Indonesia Serikat 1949 (Konstitusi RIS), yang berlaku antara Tanggal 27 Desember 1949 Sampai dengan 17 Agustus 1950.

3. Undang-Undang Dasar Sementara (UUDS) 1950, yang berlaku antara periode17Agustus1950sampaidengan 5 Juli 1959.

4. Undang-Undang Dasar 1945, yang diberlakukan kembali sejak dikeluarkannya Dekrit Presiden 5 Juli 1959 Sampai sekarang.

2. Eksistensi Majelis Permusyawaratan Rakyat Sementara dan Majelis Permusyawaratan Rakyat (MPR/S)

a. Pada Masa Orde Lama MPRS Sebagai Lembaga Tertinggi Negara

Dalam aturan pokok (UUD 1945) sebelum amandemen, dapat dilihat

${ }^{13}$ Jimly Asshiddiqie, Hukum Acara Pengujian Undang-Undang, (Jakarta : Konstitusi Press, 2006), Hal. 1.

${ }^{14}$ Nuruddin Hady, Teori Konstitusi dan Negara Demokrasi Paham Konstitusionalisme Demokrasi Pasca Amandemen UUD 1945, Cet. 1 (Malang : Setara Press 2010), Hal. 99-100 
mengenai lembaga-lembaga Negara, baik itu Lembaga Tertinggi maupun Lembaga Tinggi Negara. Struktur ketatanegaraan sebelum amandemen UUD 1945 yakni sebagai berikut: ${ }^{15}$

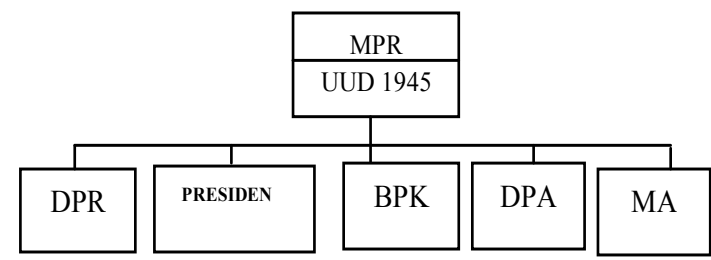

Dari struktur tersebut menyebabkan antar lembaga bisa saling menjatuhkan, hal ini terbukti dari kewenangan yang dimiliki oleh MPR. Presiden sebagai Kepala Negara harus tunduk kepada MPRS, sehingga presiden sangat mudah dijatuhkan apabila di dalam keanggotaan MPRS sudah tidak ada lagi pendukung Presiden (mossi tidak percaya). Hal ini pernah terjadi pada masa Orde Lama yang menyebabkan Pemakzulan terhadap Presiden Soekarno.

\section{b. Pada Masa Orde Baru MPR/S Masih Sebagai Lembaga Tertinggi Negara}

Perlu dipahami bahwa pada era presiden Soeharto kita dapat melihat kedudukan MPR masih sebagai lembaga tertinggi Negara. Secara otomatis kedaulatan berada di tangan MPR.

Dapatlah kita lihat, sebelum perubahan UUD 1945 kedudukan MPR sebagaiLembaga Tertinggi Negara, karena doktrin yang dianut bukan pemisahan kekuasaa, melainkan pembagian kekuasaan, dimana MPR sebagai lembaga tertinggi membagi kewenangannya kepadalembagayanglain(supremasiMPR). ${ }^{16}$

${ }^{15}$ Indonesia, Undang-Undang Dasar, dilengkapi dengan Kabinet Kerja Periode 2014-2019, Cet 1 (Yogyakarta : Pustaka Baru Press, 2014), Hal. 19

16 Mukhlis, "Kewenangan Lembaga-lembaga Negara Dalam Memutus dan Menafsirkan UUD Setelah Amandemen Keempat Undang-Undang Dasar 1945", Jurnal Syiar Hukum, Vol. 13 No. 1 (Maret 2011). Hal. 56-57

124 IUS Kajian Hukum dan Keadilan
Kekuasaan Soeharto runtuh setelah banyak desakan yang menutut Soeharto untuk mundur sebagai Presiden. Gerakan reformasi pada tahun 1998 yang diinisiasi mahasiswa dengan dibantu komponen masyarakat sudah tidak dapat terbendung lagi, sehingga secara heroik puncaknya dapat menumbangkan pemerintahan Soeharto dari jabatan Presiden pada hari Kamis, tanggal 21 Mei 1998. ${ }^{17}$ Sejak saat itu pula konsep Demokrasi mulai dikumandangkan.

Untuk menyesuaikan Negara Demokrasi, UUD 1945 diamandmen. AmandemenUndang-UndangDasar1945 terjadi sebanyak 4 (empat) kali, dimana perubahan pertama terjadi pada Tahun 1999, Tahun2000, kemudian Tahun2001, dan terakhir Tahun 2002.18 sebanyak empatkali,dariTahun1999sampaidengan tahun 2002.

c. Pada Masa Awal Demokrasi-Sekarang MPR Sebagai Lembaga Tinggi Negara Untuk Mewujudkan (Checks and Balances)

Pada tahun 1998 merupakan akhir dari kekuasaan orde baru, sehingga kursi kepresidenan diduduki oleh BJ Habibie untuk menggantikan Soeharto yang menjabat sebagai Presiden selama 32 Tahun.

Gerakan Reformasi tahun 1998 telah memberi harapan besar untuk menghantarkan bangsa Indonesia melakukan pembaharuan dalam penyelenggaraan Negara, sebagai suatu Negara yang demokratis, berdasarkan hukum dan konstitusional.19Sehingga, Konsep demokrasi berkaitan dengan harkat

${ }^{17}$ Warsito, "Implikasi Amandemen UUD 1945 Terhadap Kedudukan, Fungsi, Tugas dan Wewenang Majelis Permusyawaratan Rakyat (MPR)" Jurnal Supremasi Hukum, Vol. 11 No. 1 (Januari 2015). Hal. 85

${ }^{18}$ Asri Agustiwi, Keberadaan Lembaga Negara Pasca Amandemen Undang-Undang Dasar 1945 di Indonesia, Jurnal Rechstaat, Vol. 8 No. 1 (Maret 2014). Hal. 1

${ }_{19}$ Sri Nur Hari Susanto, "Pergeseran Kekuasaan Lembaga Negara Pasca Amandemen UUD 1994", Jurnal 
kemanusiaan dan otonomi individu yang luas. Oleh karena itu, pemerintahan demokrasiadalah pemerintahan dari rakyat, oleh rakyat, dan untuk rakyat. Dengan demikian sistem demokrasi selalu dikaitkan dengan sistem kedaulatan rakyat, karena rakyatlah yang memiliki kekuasaan tertinggi. ${ }^{20}$

Pada Tahun 1999 Abdurrahman WahidterpilihsebagaipresidenRIsetelahdipilih oleh anggota MPR. Dengan jabatannya sebagai presiden, Presiden Abdurrahman Wahid menjalankan pemerintahannya dengan sikap dan kebijakan kontroversial.21 Pada akhirnya Pemakzulan dengan mekanisme politik terhadap Presiden Abdurrahman Wahid terjadi.

Suatu wujud terciptanya checks and balances dapat di lihat setelah Perubahan UUD 1945. Lihat bagan berikut ini :22

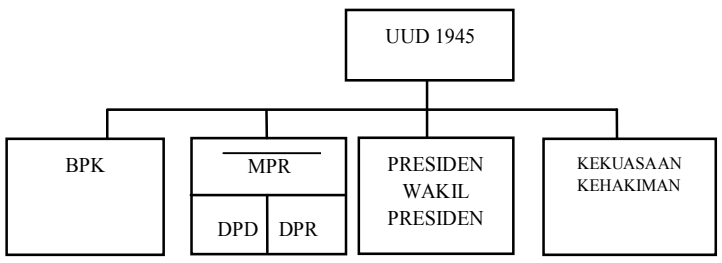

Amandemen UUD 1945 berpengaruh pada perubahan lembaga Negara menjadi Lembaga Tinggi Negara yang saling mengawasi antara lembaga yang satu maupun lembaga Negara yang lainnya.

3. Materi Muatan Ketetapan MPR/S yang Bersifat Mengatur (Regeling) Membawa Implikasi Pada Berlakunya Sebagai Peraturan PerundangUndangan

Majelis Permusyawaratan Rakyat Sementara atau Majelis Permusyawaratan Rakyat (MPR/S) mengeluarkan Ketetapan sebanyak 139 Ketetapan. Namun dengan perubahan struktur ketatanegaraan, 139

Masalah-Masalah Hukum, Vol. 43 No. 2 (April 2014). Hal. 279

${ }^{20}$ Hamdan Zoelva, Pemakzulan Presiden di Indonesia, Cet. 1 (Jakarta : Sinar Grafika, 2011). Hal. 18

${ }^{21}$ Ibid, Hal. 143 119

22 Indonesia, Undang-Undang Dasar, Op. Cit Hal. ketetapan itu sudah dilakukan peninjauan kembali oleh MPR (Lembaga Tinggi Negara) hasil amandemen UUD 1945. Ketetapan MPR RI No. I/MPR/2003 Tentang peninjauan terhadap Materi dan Status Hukum Ketetapan Majelis Permusyawaratan Rakyat Sementara dan Ketetapan Majelis Permusyawaratan Rakyat Republik Indonesia Tahun 1960 Sampai dengan Tahun 2002. ${ }^{23}$

Berdasarkan pengelompokan di atas, maka TAP MPR yang masih dianggap berlaku tertuang dalam Pasal 2 dan Pasal 4, dengan total sebanyak 13 TAP MPR yang masih berlaku. TAP MPR yang masih berlaku tersebut, adalah :24

1. Ketetapan MPRS No. XXV/MPRS.1966 tentang Pembubaran Partai Komunis Indonesia, pernyataan sebagai organisasi terlarang di seluruh Wilayah Indonesia bagi Partai Komunis Indonesia dan larangan setiap Kegiatan untuk Menyebarkan atau Mengembangkan Faham atau Ajaran Komunisme/ Marxisme-Leninisme.

2. Ketetapan MPR No. XVI/MPR/1998 tentang Politik Ekonomi Dalam Rangka Demokrasi Ekonomi.

3. Ketetapan MPR No V/MPR/1999 tentang Penentuan Pendapat di Timor Timur.

4. Ketetapan MPRS No. XXIX/MPRS/1966 tentang Pengangkatan Pahlawan Ampera. (dalam perkembangan terakhir telah terbentuk UU No. 20 Tahun 2009 tentang Gelar,TandaJasa,danTandaKehormatan)

5. Ketetapan MPR No. XI/MPR/1998 tentangPenyelenggara NegarayangBersih dan Bebas KKN.

${ }^{23}$ Indonesia, Majelis Permusyawaratan Rakyat Indonesia, Ketetapan MPR RI No. I/MPR/2003, Cet. Ke 10, Sekretariat Jendral MPR RI 2011. Hal. XV

24 http://www.herdi.web.id/kedudukan-tap-mpr-dalam-sistem-perundang-undangan-indonesia. di akses Pada Tnggal 20 November 2015. 
6. Ketetapan MPR No. XV/MPR/1998 tentang Penyelenggaraan Otonomi Daerah, Pengaturan, Pembagian, dan Pemanfaatan Sumber Daya Nasional yang Berkeadilan,sertaPerimbanganKeuangan Pusat dan Daerah dalam NKRI.

7. KetetapanMPRNo.V/MPR/2000tentang Pemantapan Persatuan dan Kesatuan Nasional.

8. Ketetapan MPR No. VI/MPR/2000 tentang Pemisahan Tentara Nasional Indonesia dan Kepolisian Negara Indonesia.

9. Ketetapan MPR No. VII/MPR/2000 tentang Peran TNI dan Peran Polri.

10. Ketetapan MPR No. VI/MPR/2001 tentang Etika Kehidupan Berbangsa.

11.Ketetapan MPR No. VII/MPR/2001 tentang Visi Indonesia Masa Depan.

12. Ketetapan MPR No. VIII/MPR/2001 tentang Rekomendasi Arah Kebijakan Pemberantasan dan Pencegahan KKN.

13. Ketetapan MPR No. IX/MPR/2001 tentang Pembaharuan Agraria dan Pengelolahan Sumber Daya Alam.

Maksud dari Ketetapan MPR/S yang materi muatannya bersifat mengatur (regeling) itu hanya Ketetapan yang tertuang dalam Ketetapan MPR No. I/ MPR/2003 Tentang Peninjauan Terhadap Materi dan status hukum Ketetapan MPRS dan Ketetapan MPR RI Tahun 1960 Sampai Tahun 2002. Berarti dapat dipahami bahwa hanya 13 Katetapan itulah yang di akui sebagai peraturan perundang-undangan sebagaimana tercantum di dalam hierarki peraturan perundang menurut UU No. 12 Tahun 2011 Tentang Pembentukan Peraturan Perundang-Undangan Pasal 7 Ayat (1) huruf b.

\section{Jalan Pikiran Pembentuk Un- dang-Undang Terhadap Ketetapan MPR/S}

Perlu kita telusuri jalan pikiran para pembentuk UU No. 10 Tahun 2004 Tentang Pembentukan Peraturan Perundang-Undangan yang tidak mencantumkan Ketetapan MPR/S pada tatanan hierarki. Kemudian selanjutnya, perlu pula ditelusuri jalan pikiran pembentuk UU No. 12 Tahun 2011 Tentang Pembentukan Peraturan Perundang-Undangan yang mencantumkan kembali Ketetapan MPR/S ke dalam hierarki Peraturan Perundang-Undangan.

a. Dasar Pertimbangan Pembentuk UU No. 10 Tahun 2004, Mengeluarkan Ketetapan MPR/S dari Hierarki PerundangUndangan.

Selama 34 (tiga puluh empat) Tahun TAP MPRS No. XX/MPRS/1966 berlaku, hingga pada Tahun 2000 MPR mengeluarkan Ketetapan untuk menyempurnakan kekurangan yang terdapat pada TAP MPRS No. XX/MPRS/1966.

Pada Tahun 2003 MPR mengeluarkan produk Ketetapan, hal tersebut merupakan amanat dari UUD 1945 yang merupakan implikasi dari hasil amandemen. Ketetapan yang dimaksud adalah Ketetapan MPR RI No. I/MPR/2003 Tentang Peninjauan Terhadap Materi Dan Status Hukum Ketetapan MPRS dan MPR RI Tahun 1960 Sampai Dengan Tahun 2002. Pasal 4 dan Ayat (4) pada Ketetapan MPR RI No. I/ MPR/2003 dapat dilihat sebagai berikut : ${ }^{25}$

Pasal 4 KetetapanMajelisPermusyawaratan Rakyat Sementara dan Ketetapan Majelis Permusyawaratan Rakyat Republik Indonesia sebagaimana dimaksud di bawah ini tetapberlakusampaidenganterbentuknya undang-undang.

Ayat (4) Ketetapan Majelis Permusyawaratan Rakyat Republik Indonesia Nomor III/MPR/2000 tentang Sumber Hukum dan Tata Urutan Peraturan Perundang-undangan.

\footnotetext{
25 Sekretariat Jendral MPR RI, Ketetapan MPR RI No. I/MPR/2003, Cet, Ke 10 (Jakarta : 2010), Hal. 13
} 
M. Saoki Oktava|Eksistensi Ketetapan MPR/S Dalam Hierarki Peraturan Perundang-Undangan.........

Sebagaimana bunyi Pasal 4 dan Ayat (4) pada Ketetapan MPR RI No. I/MPR/2003 tersebut di atas yang merekomendasikan untuk terbentuknya suatu UU yang menggantikan Ketetapan MPR RI No. III/MPR/2000. Sehingga, Pasal tersebut adalah dasar hukum untuk lahirnya UU No. 10 Tahun 2004 Tentang Pembentukan Peraturan Perundang-Undangan. UU No. 10 Tahun 2004 Pasal 7 dapat dilihat yaitu:

1. Undang-Undang Dasar Negara Republik Indonesia Tahun 1945;

2. Undang-Undang/peraturan pemerintah pengganti Undang-Undang;

3. Peraturan Pemerintah;

4. Peraturan Presiden;

5. Peraturan Daerah;
a. Perda Provinsi
b. Perda Kabupaten/Kota
c. Perdes/Peraturan yang setingkat

Jika menurut Maria Farida, pada risalah pembentukan Undang-Undang Nomor 10 Tahun 2004. Terkait dengan tidak tercantumnya Ketetapan MPR/S, di dalam risalahnya dikatakan bahwa, karena MPR itu tidak lagi mempunyai kewenangan menetapkan Garis-Garis Besar Haluan Negara, maka kemudian para pembentuk undang-undang waktu itu mengatakan kalau begitu tidak ada lagi TAP MPR. Maka para pembentuk Undang-Undang Nomor 10 Tahun 2004 meletakan TAP MPR itu tidak ada dalam daftar. ${ }^{26}$

Berikutnya dapat dilihat pertimbangan keluarnya Ketetapan MPR/S dari tatanan hierarki, pertimbangan tersebut ada pada proses pembahasan Rancangan Undang-

${ }^{26}$ Mahkamah Konstitusi Republik Indonesia, Risalah Sidang, Perkara No. 86/PUU-XI/2013, Perihal Pengujian Pasal 7 Ayat (1) huruf b Undang-Undang No. 12 Tahun 2011 Tentang Pembentukan Peraturan Perundang-Undangana Terhadap Undang-Undang Dasar Negara Republik Indonesia Tahun 1945. Hal. 3
Undang Republik Indonesia Tentang Pembentukan Peraturan Perundangundangan.

Jika kita menelusuri risalah proses pembahasan rancangan Undang-Undang Republik Indonesia tentang pembentukan peraturan perundang-undangan, kita dapat melihat pada sambutan pemerintah atas persetujuan RUU tentang pembentukan peraturan perundang-undangan pada Tanggal 24 Mei 2004. Bahwa, ada beberapa substansi penting dalam RUU tentang Pembentukan Peraturan Perundang-undangan yang dalam proses pembahasannya mendapat perhatian mendalam termasuk "jenis hierarki peraturan perundang-undangan" dan "Istilah Peraturan". Hal tersebut dapat dilihat sebagai berikut : ${ }^{7}$

1. Jenis dan Hierarki Peraturan perundangundangan merupakan pembahasan inti dari substansi RUU ini karena jenis dan hierarki peraturan perundang-undangan sebagai landasan tingkatan hierarki penyusunan peraturan perundangundanganbaikdiPusatmaupundiDaerah.

2. Istilah "Peraturan"

Telah disepakati bahwa untuk menjaga konsistensi penyebutan peraturan perundang-undangan yang bersifat mengatur digunakan istilah "Peraturan". Halini dimaksudkan agar tidaklagi terjadi atau timbul pertanyaan mengenai istilah "Keputusan" yangbersifatmengaturataupun yang bersifat penetapan.

Dari apa yang telah disampaikan pada sambutan pemerintah atas persetujuan rancangan undang-undang tentang

${ }^{27}$ www.dpr.go.id, Layanan Informasi Publik, Pejabat Pengelola Informasi dan Dokumentasi (PPID) DPRRI, Proses Pembahasan, Rancangan Undang-Undang Republik Indonesia Tentang Pembentukan Peraturan Perundang-Undangan, Biro Persidangan Dewan Perwakilan Rakyat Republik Indonesia 2004, Sambutan Pemerintah atas Persetujuan Rancangan Undang-Undangan Tentang pembentukan Peraturan Perundang-undangan dalam rapat paripurna terbuka Dewan Perwakilan Rakyat Republik Indonesia, Hal. 4 
pembentukan peraturan perundangundangan tersebut di atas, penulis berpendapat bahwa pada poin yang kedua terhadap istilah "peraturan" adalah peraturan perundang-undangan, maksudnya terhadap produk Ketetapan dan Keputusan tidak termasuk peraturan perundang-undangan, sekalipun materi muatannya bersifat regeling. Sehingga RUU tersebut menganut paham bahwa suatu Ketetapan dan Keputusan bukan merupakan peraturan perundangundangan meskipun materi muatannya mengandung norma umum, hal tersebut untuk menjaga konsistensi terhadap istilah "Peraturan". Sehingga, pada waktu itudiperolehkesepakatanterhadapproduk Ketetapan MPR/S untuk dikeluarkan dari tatanan hierarki peraturan perundangundangan.

Hingga pada akhirnya RUU yang disepakati bersama tersebut disetujui dan disahkan menjadi UU oleh Presiden pada Tanggal 22 Juni 2004 dan resmi di undangkan ke dalam lembaran negara. Sehingga berlakulah UU No. 10 Tahun 2004 Tentang Pembentukan Peraturan Perundang-Undangan. Di dalam UU tersebut tidak ada lagi Ketetapan MPR/S dalam tata urutan hierarki peraturan perundang-undangan.

Padahal seperti yang kita ketahui bahwa, Ketetapan MPR/S yang masih berlaku menurut Ketetapan MPR RI No. I/MPR/2003, materi muatannya adalah bersifat mengatur regeling. Meskipun demikian, tetap saja Ketetapan MPR/S dan Keputusan Presiden yang pernah diatur oleh Ketetapan MPR RI No. III/ MPR/2000 tidak tercantumlagidalamUU No.10Tahun2004TentangPembentukan Peraturan Perundang-Undangan. Dengan demkian, di keluarkannya dari tatanan hierarkidapatmenimbulkankonsekuensi terhadap eksistensi Ketetapan MPR/S yang juga sebagai peraturan perundangundangan yang tentunya akan menimbulkan ketidakpastian hukum terhadap Keberadaan Ketetapan MPR/S yang masih berlaku. Oleh karena itu agar suatu norma hukum yang ada di bawah berlaku, maka norma hukum yang ada di atasnya harus di perkuat sebagai landasanbagiaturanyangadadibawahnya sebagaimana menurut teori Adolf Melker dalam Teori Dua Wajah Norma Hukum.

b. Dasar Pertimbangan Para Pembentuk UU No. 12 Tahun 2011, Mencantumkan Ketetapan MPR/S Dalam Hierarki Perundang-Undangan.

Selama tujuh tahun UU No. 10 Tahun 2004 berlaku dan berimplikasi pada eksistensi peraturan perundang-undangan yang berlandaskan pada Ketetapan MPR/S. Misalnya persoalan ada Pada UU KPK dan eksistensi lembaga KPK yang memberantas korupsi. Pertanyaannya mengapa Lembaga KPK yang dibentuk oleh Undang-Undang tetap eksis? Padahal UU tersebut berlandaskan Ketetapan MPR No. XI/MPR/1998 tentang Penyelenggara Negara yang Bersih dan Bebas KKN dan Ketetapan MPR No. VIII/MPR/2001 tentang Rekomendasi Arah Kebijakan Pemberantasan dan Pencegahan KKN. Sehingga keberlakuan dari UU No. 10 Tahun 2004 Tentang Peraturan Perundangundangan pada saat itu yang meniadakan Ketetapan MPR/S harus dipertanyakan karena pada Pasal 7 keberlakuan UU diakui sedangkan Ketetapan MPR/S yang menjadi acuan dari beberapa UU ditiadakan, tentu ini merupakan hal yang keliru. Sehingga terbentuknya UU No. 12 Tahun 2011 Tentang Pembentukan Peraturan Perundang-undangan yang mengembalikan Ketetapan MPR/S ke dalam hierarki merupakan suatu tindakan yang tepat. Oleh karena itu, penulis berpendapat setelah terbentuknya UU No. 12 Tahun 2011, sangatlah penting jika Ketetapan MPR/S di akui dalam tatanan hierarki, implikasinya dapat pula memberikan jaminan kepastian hukum terhadap Ketetapan MPR/S 
maupun beberapa UU yang berlandaskan pada Ketetapan MPR/S. Dalam artian keberadaan UU pun akan jelas.

Kejelasan itu dapat dirasakan setelah terbentuknya UU No. 12 Tahun 2011 Tentang Pembentukan Peraturan Perundang-undangan Pasal 7 Ayat (1) huruf b. Namun, sebelum UU No. 12 Tahun 2011 disahkan, kita dapat melihat pada proses pembahasan RUU tersebut, yakni RUU tentang pembentukan peraturan perundang-undangan.

RUU tentang Pembentukan Peraturan Perundang-undangan adalah RUU Usul Inisiatif DPR RI yang dipersiapkan oleh Badan Legislasi dan disampaikan kepada Pimpinan DPR RI pada tanggal 25 Agustus 2010. Atas dasar itu melalui proses di DPR RI telah membentuk Pansus RUU tentang Pembentukan Peraturan Perundangundangan yang pembentukannya telah disahkan pada Rapat Paripurna Dewan pada Tanggal 27 September 2010.28

Di dalam rapat pansus RUU pembentukan peraturan perundang-undangan memunculkan berbagai pandangan yang terjadi dalam risalah rapat tersebut yang berkaitan dengan eksistetnsi dari Ketetapan MPR/S untuk kembali tercantum pada tatanan hierarki peraturan perundang-undangan. Upaya tersebut menempatkannya kembali berada di bawah Undang-Undang Dasar 1945.

Rusli Ridwan misalnya, dari Fraksi PAN mengatakan Undang-Undang Dasar 1945 adalah aturan pokok, dan TAP MPR juga merupakan aturan pokok, hanya saja aturan pokok yang dituangkan dalam TAP MPR itu adalah merupakan penjabaran kebijakan dari batang tubuh Undang-Undang Dasar. Pada Pasal 3 dulu sebelum perubahan

${ }^{28}$ www.dpr.go.id, Layanan Informasi Publik, Pejabat Pengelola Informasi dan Dokumentasi (PPID) Sekretariat Jendral DPR-RI, Risalah Rapat Panitia Khusus Rancangan Undang-Undang Tentang Pembentukan Pertaturan Perundang-Undangan, Jenis Rapat : Raker I Tanggal : 13 Desember 2010. Hal. 3 tentang GBHN, GBHN itu ditetapkan oleh MPR, itu berada di bawah, karena pada saat itu menjabarkan apa isi dari pada GBHN itu tidak boleh bertentangan dengan batang tubuh untuk dilaksanakan oleh Presiden. Jadi mengamanatkan kepada kita melaksanakan GBHN, GBHN ini tidak boleh bertentangan isi dari pada batang tubuh.Jadi TAP MPR itu posisinya di bawah UndangUndang Dasar.29 Berikutnya lagi, Rusli Ridwan mengatakan, memang sejak awal punya keinginan terhadap TAP MPR harus masuk dalam hierarki, pertimbangannya itu adalah dalam rangka daya laku, daya guna, sekaligus juga kepastian hukum. 30

Pandangan selanjutnya disampaikan oleh Fraksi Partai Demokrat Himmatul Alyah Setiawati mengatakan :31

"Sebenarnya ini prinsip karena kebetulan saya juga sama Pak Tjipto kan kita ada di Tim MPR dan saya ada di sosialisasi untuk TAP MPR, jadi ini jadi gongnya jadi Demokrat bahwa kedudukannya bahkan kalau bisa langsung di bawah UndangUndang Dasar karena kembali kepada susunan sebelum ada perubahan UndangUndang Dasar 1945".

Hingga pada hari Jum'at, 22 Juli 2011 diperoleh kesepakatan antara DPR dan Pemerintah yang diwakilkan oleh Menteri Hukum dan HAM Parialis Akbar, dengan menyetujui RUU Pembentukan Peraturan Perundang-Undangan. Kesepakatan ini dicapai dalam rapat paripurna DPR.32

Dapatlah kita lihat, dari pengusulan hingga kesepakatan mencantumkan

\footnotetext{
${ }^{29}$ www.dpr.go.id, Layanan Informasi Publik, Pejabat Pengelola Informasi dan Dokumentasi (PPID) Sekretariat Jendral DPR RI, Lebih lengkapnya lihat Pandangan Rusli Ridwan Fraksi PAN, dalam Risalah Rapat Panitia Khusus Rancangan Undang-Undang Tentang Pembentukan Peraturan Perundang-Undangan, Jenis Rapat : Raker IV Tanggal 2 Maret 2011. Hal 27

${ }^{30}$ bid. Hal 22

${ }^{31} \mathrm{Ibid}$.

32 www.hukumonline.com, Hierarki Peraturan Perundang-undangan Berubah, (Jum'at 22 Juli 2011), di akses oleh penulis pada Tanggal, 20 Desember 2015.
} 
kembali Ketetapan MPR/S dalam hierarki yang tentunya memberikan dampak posistif terhadap Ketetapan MPR/S yang masih berlaku, karena perlu diketahui bahwa pentingnya Ketetapan MPR/S tercantum dalam hierarki sangat membawa berpengaruh besar terhadap penegakan hukum di Indonesia, seperti yang telah penulis bahas pula sebelumnya terhadap Ketetapan MPR yang masih berlaku yang termasuk juga sebagai peraturan perundang-undangan yakni Ketetapan MPR No. VIII/2001 Tentang Rekomendasi Arah Kebijakan Pemberantasan dan Pencegahan Korupsi, Kolusi dan Nepotisme. Sehingga dapat dilihat pada Pasal 2 yaitu:33

Arah kebijakan pemberantasan korupsi, kolusi dan nepotisme adalah :

1. Mempercepat proses hukum terhadap aparatur pemerintah terutama aparat penegak hukum dan penyelenggara negara yang diduga melakukan praktek korupsi,kolusi,dan nepotisme,sertadapat dilakukan tindakan administratif untuk memperlancar proses hukum.

2. Melakukan penindakan hukum yanglebih bersungguh-sungguh terhadap semua kasus korupsi, termasuk korupsi yang telah terjadi dimasa lalu, dan bagi mereka yang telah terbukti bersalah agar dijatuhi hukuman yang seberat-beratnya.

3. Mendorong partisipasi masyarakat luas dalam mengawasi dan melaporkan kepada pihak berwenang berbagai dugaan praktek korupsi, kolusi, dan nepotisme yang dilakukan oleh pegawai negeri, penyelenggara negara dan anggota masyarakat.

4. Mencabut, mengubah, atau mengganti semua peraturan perundang-undangan serta keputusan-keputusan penyelenggara negara yang berindikasi melindungi

${ }^{33}$ Indonesia, Ketetapan MPR RI No. VIII/2001 Tentang Rekomendasi Arah Kebijakan Pemberantasan dan Pencegahan Korupsi, Kolusi dan Nepotisme. atau memungkinkan terjadinya korupsi, kolusi, dan nepotisme.

5. Merevisi semua peraturan perundangundanganyangberkenaandengankorupsi sehingga sinkron dan konsisten satu dengan yang lainnya.

6. Membentuk Undang-undang beserta peraturan pelaksanaannya untuk pencegahan korupsi yang muatannya meliputi :
a.Komisi Pemberantasan Tindak Pidana Korupsi;
b.Perlindungan Saksi dan Korban;
c. Kejahatan Terorganisasi;
d.Kebebasan Mendapatkan Informasi;
e. Etika Pemerintahan;
f. Kejahatan Pencucian Uang;
g. Ombudsman.

7. Perlu segera membentuk Undang-undang guna mencegah terjadinya perbuatanperbuatan kolusi dan/atau nepotisme yang dapat mengakibatkan terjadinya tindak pidana.

Menurut penulis Ketetapan tersebut yang menjadi landasan bagi aturan-aturan di bawahnya di mana pada Pasal 2 angka 4 sebagaimana diatur pada Ketetapan MPR No. VIII/2001 tersebut di atas dapat dilihat adanya suatu penekanan terhadap keberlakuan dari aturan yang ada di bawahnya untuk tidak bertentangan dengan Ketetapan MPR tersebut. Maksud dari tidak bertentangan yakni kepada aturan di bawahnya, tidak hanya sekedar mengatur, tetapi aturan tersebut harus pula dapat memberikan efek jera terhadap para Koruptor yang dihukum. Sehingga Hukumannya harus yang seberat-beratnya. Ini sebagai bukti bahwa Ketetapan MPR/S merupakan peraturan perundang-undangan yang harus diperkuat dalam tatanan hierarki. 
M. Saoki Oktava|Eksistensi Ketetapan MPR/S Dalam Hierarki Peraturan Perundang-Undangan.........

3. Pertimbangan Hukum Tercantumnya Ketetapan MPR/S dalam Hierarki Perundang-Undangan

Di Indonesia pertama kali mengeluarkan aturan yang mengatur tata urutan peraturan perundang-undangan pada Tahun 1966. Aturan tersebut dapat terlihat pada TAP MPRS No. XX/MPRS/1966. Ini mencerminkan bahwa Ketetapan MPRS berlaku sebagai peraturan perundangundangan karena sifat materi muatannya regeling sehingga mengaharuskan TAP MPRS di akui sebagai tata urutan hierarki perundang-undangan.

Oleh karena itu, segala ketetapan yang dikeluarkanya mempunyai kedudukan yang lebih tinggi dari produk hukum yang ditetapkan oleh Lembaga-Lembaga Tinggi Negara yang lain, seperti presiden, DPR, Mahkamah Agung. Dengan demikian, Ketetapan MPR/S lebih tinggi kedudukan hierarkinya dari Undang-Udang ataupun bentuk-bentuk peraturan lainnya. ${ }^{34}$

Itulah yang menjadi salah satu faktor tetap eksisnya Ketetapan MPR/S sebagai peraturan perundang-undangan. Eksistensi dari Lembaga MPR/S yang pernah sebagai Lembaga Tertinggi Negara menurut UUD 1945 sebelum amandemen membawa implikasi terhadap eksistensi dari Ketetapan yang dikeluarkannya. Meskipun setelah amandemen UUD 1945 MPR menjadi Lembaga Tinggi Negara yang sederajat dengan lembaga tinggi lainnya, namun hal tersebut tidak berpengaruh pada Ketetapan MPR/S yang masih berlaku dan bersifat regeling, karena Ketetapan MPR/S dari Tahun 1960 sampai dengan Tahun 2002 merupakan produk hukum yang dikeluarkan oleh MPR/S yang pernah menjadi Lembaga Tertinggi Negara. Berarti, menurut penulis Kedudukan Ketetapan MPR/S otomatis berada di atas UU sebagaimana tercantum dalam Pasal 7 Ayat (1) huruf b UU No.

${ }^{34}$ Jimly Asshiddiqie, Perihal Undang-Undang, Cet Ke. 3 (Jakarta : Raja Grafindo Persada, 2014). Hal. 33
12 Tahun 2011 Tentang Pembentukan Peraturan Perundang-undangan.

4. Pentingnya Ketetapan MPR/S Tercantum dalam Hierarki Peraturan perundangundangan dan Kaitannya dengan Putusan MK Nomor 86/PUU-XI/2013

Pada Tahun 2013 UU No. 12 Tahun 2011 Pasal 7 Ayat (1) huruf b pernah di Judicial Review di Mahkamah Konstitusi, dimana para pemohon yang di wakilkan oleh 3 (tiga) orang yakni Viktor Santoso Tandiasa, Kurniawan, dan Joko Widarto menginginkan TAP MPR/S keluar dari hirarki peraturan perundang-undangan, pemohon menguraikan bahwa keberadaan TAP MPR menjadi polemik ketatanegaraan yang kita tahu bersama sudah beberapa tahun ini tidak ada lembaga negara satu pun yang berwenang dalam menguji TAP MPR tersebut, sehingga terjadi kekosongan hukum ketika ada warga negara yang hak konstitusionalnya dirugikan kemudian tidak bisa menguji TAP MPR, karena bertentangan dengan Undang-Undang Dasar $1945 .^{35}$

Para pemohon merujuk pada kasus yang pernah terjadi di Mahkamah Konstitusi pada saat Rahmawati Soekarno Putri mengajukan permohonan pengujian TAP MPR RI No. I Tahun 2003, ternyata ditolak oleh Mahkamah Konstitusi. Artinya terjadi kebingungan oleh pihak Rahmawati Soekarno Putri, oleh karena itu para pemohon menganggap bahwa Pasal 7 ayat (1) huruf b, keberadaan TAP MPR/S merugikan hak konstitusional warga Negara karena tidak ada jaminan hukum perlindungan maupun kepastian yang telah diamanatkan di dalam Undang-Undang Dasar 1945 Pasal 28D Ayat (1). Menurut pemohon dalam risalah sidang menyatakan (ini sangat bertentangan dan ini persoalan serius yang mungkin harus diselesaikan segera).36 Sehingga maksud dari para pemohon tersebut, men-

\footnotetext{
${ }^{35}$ Mahkamah Konstitusi Republik Indonesia, Risalah Sidang, Perkara No. 86/PUU-XI/2013, Op. Cit. Hal. 2

${ }^{36}$ Ibid, Hal.2-3
} 
ginginkan Ketetapan MPR/S agar keluar dari tatanan hierarki karena, yang pertama : terjadinya kekosongan norma hukum terhadap lembaga yang menguji Ketetapan MPR/S, Kedua : Masyarakat menjadi bingung, mau di uji kemana Ketetapan MPR/S yang masih berlaku.

Mengutip bagian dari pernyataan Hakim Konsitusi Maria Farida Indarti, dalam risalah sidang Mahkamah Konstitusi Perihal Pengujian UU No. 12 Tahun 2011 Terhadap UUD 1945 adalah :

"Nah, di sini tadi warga negara Anda mengatakan Pemohon adalah Pemohon memberi kepentingan konstitusional atas diberlakukannya Pasal 7 ayat (1) dan Pemohon bisa merugikan hak konstitusional Pemohon maupun warga negara Indonesia. Kalau Anda melihat pada TAPTAP MPR, TAP itu sebetulnya mengatur siapa. TAP itu mengatur rakyat, mengatur kita, atau mengatur presiden, nah di situ ditetapkan. Kalau ada TAP yang keliru Tapi bahwa TAP MPR itu dibuat untuk presiden karena presiden dulu adalah mandatarisnya MPR. Jadinya, kalau Anda mengatakan Pemohon apakah Anda terkena dengan TAP-TAP MPR tersebut katanya ya kan? Itu dilihat.

Kemudian kita bisa melihat di sini bahwa dalam alasan permohonan Anda, Anda mengatakan struktur ketatanegaraan yang semua terbagi lembaga tertinggi dan tinggi negara menjadikan tidak ada lembaga tertinggi negara. Kesamaan posisi dari lembaga negara yang ada, menunjukkan adanya kewenangan satu dengan yang lain yang pada tugasnya masingmasing tidak saling menjatuhkan satu terhadap yang lain. Ya kan? Memang ada yang bisa menjatuhkan di sini? Kecuali $M P R$ bisa memecat presiden. Tapi dengan prosedur DPR. Mengajukan ke MK dulu, yakan?
Kita bisa melihat di sini, ada beberapa permasalahan yang saya akan ... keberadaan TAP MPR di Undang-Undang Nomor 10 tidak diakui. Akan tetapi, norma yang diatur dalam setiap TAP MPR sejak tahun 1966, Anda ini halaman 10, nomor 6, sejak tahun 1966 hingga tahun 2002, tetap diakui sebagai produk hukum yang berlaku, sepanjang tidak digantikan dengan undang-undang formal yang ditetapkan setelahnya.

Berarti, Anda mengatakan Anda setuju bahwa TAP MPR yang masih ada sejak tahun 1966 sampai sekarang, saya rasa itu hanya 13 itu, kalau dia belum diatur dengan undang-undang, maka dia masih tetap berlaku. Kalau demikian, mau diletakkan di mana TAP MPR itu? Kalau tidak masuk di dalam hierarki perundangundangan.

Permasalahannya sebetulnya di dalam secara teori, kita bisa melihat bahwa kalau kita mengatakan dengan hierarki peraturan-peraturan negara, tidak masalah kita mengatakan Undang-Undang Dasar Tahun 1945, TAP MPR, tapi kalau kita melihat pada hierarki perundang-undangan, maka secara teori yang termasuk perundang-undangan itu adalah undangundang ke bawah.

Nah, sekarang kalau ada TAP MPR yang masih ada dan oleh lembaga yang membentuknya sendiri dikatakan dia masih tetap berlaku, apakah kita telantarkan itu? Di sini, Anda juga mengutip bahwa dapat dikatakan sebagai salah satu sumber hukum. Kalau ada TAP tentang reformasi agraria, yang memerintahkan perlunya ada undang-undang yang mereformasi agraria, undang-undang yang sampai sekarang belum ada, mereka melihat pada Undang-Undang Nomor 5 Tahun 1960. Apakah itu tidak bisa menjadikan sumber 
M. Saoki Oktava|Eksistensi Ketetapan MPR/S Dalam Hierarki Peraturan Perundang-Undangan.........

bagi undang-undang tersebut?

Nah, jadi di sini kita bisa melihat bahwa ada hal-hal yang kita tidak bisa. Kita tidak hanya berbicara secara tataran teori. Tapi kalau pembentuknya sendiri sudah mengatakan, "Tidak boleh diapa-apakan, dinyatakan masih berlaku," maka bagaimana kita lembaga-lembaga yang katanya tadi setingkat, itu kemudian mengatakan, "Ini enggak boleh".",37

Pernyataan dari Hakim Konstitusi Maria Farida tersebut, penulis memahami akan pentingnya Ketetapan MPR/S yang masih berlaku dan bersifat (regeling) untuk tercantum dalam hierarki peraturan perundang-undangan, tujuannya tentu untuk memberikan jaminan kepastian hukum terhadap Ketetapa MPR/S.

Berhubungan dengan itu, Ketetapan yang masih berlaku yang masih menjadi sumber hukum, akan sangat riskan jika tidak diakui dalam tatanan hierarki, hal tersebut dapat penulis contohkan yaitu Ketetapan MPRS No. XXV/MPRS/1966 Tentang Pembubaran PKI. Pernyataan Sebagai Organisasi Terlarang di Seluruh Wilayah Negara Republik Indonesia dan Larangan Setiap Kegiatan untuk Menyebarkan atau Mengembangkan Faham atau Ajaran Komunisme/Marxisme-Linimisme. Dimana Pergerakan komunis merupakan suatu tindakan yang bertentangan dengan nilainilai pancasila, karena pancasila adalah sumber dari segala sumber hukum yang merupakan landasan falsafah Negara Republik Indonesia. Maka sangatlah patut jika Ketetapan MPR/S tercantum dalam hierarki peraturan perundang-undangan. Meskipun pada Tahun 2015 sedang gencargencarnya pihak anggota keluarga PKI menuntut Negara sampai ke peradilan HAM di Den Haag Belanda, menuntut agar negara meminta maaf kepada keluarga korban 1965.

\footnotetext{
${ }^{37}$ Ibid. Hal. 5
}

Ketetapan MPRS No. XXV/MPRS/1966 merupakan salah satu dari ke 13 Ketetapan yang harus diperkuat. Berkaitan dengan pentingnya Ketetapan tercantum dalam tatanan hierarki, penulis dapat mencontohkan lagi dengan Ketetapan MPR No. XI/ MPR/1998 Tentang Penyelenggaraan Negara yang Bersih dan Bebas KKN. Ketetapan ini masih berlaku dan tetap menjadi sumber hukum dalam sistem hukum nasional Negara Republik Indonesia. Lembaga KPK adalah lembaga yang menjalankan cita-cita Negara seperti yang tertuang dalam TAP MPR No. XI/MPR/1998. Lembaga KPK adalah lembaga yang sifatnya Independen, artinya lembaga KPK tidak dapat dipengaruhi oleh pemerintah.

KPK lahir pada Tanggal 29 Desember Tahun 2003, sebelumnya berlaku UU No. 30 Tahun 2002 Tentang Komisi Pemberantasan Tindak Pidana Korupsi. Sembelumnya juga, pada Tahun 1999 lahir UU No. 31 Tahun 1999 diganti dengan UU No. 20 Tahun 2001 Tentang Pemberantasan Tindak Pidana Korupsi. Ini merupakan bentuk untuk tercapainya penyelenggaraan Negara yang bersih dan bebas KKN.

Tindak Pidana Korupsi (Tipikor) adalah suatu perilaku yang semakin populer di Perbincangkan di media-media, prilaku korupsi sedang menggerogoti Negara Indonesia baik dilakukan oleh pejabat di tingkat Daerah sampai di tingkat Pusat (Nasional). Tentu ini merupakan suatu tindakan yang melanggar norma-norma dalam sistem hukum nasional.

Dalam upaya untuk mewujudkan Negara yang bersih dan bebas KKN sesuai dengan cita-cita Negara Republik Indonesia yang tercantum dalam Ketetapan MPR No. IX/MPR/1998, Lembaga KPK dan UU No 31 Tahun 1999 jo UU No. 20 Tahun 2001 Tentang Tindak Pidana korupsi dibentuk dengan berlandaskan Ketetapan MPR No. IX/MPR/1998, sehingga lembaga anti korupsi KPK menjalankan amanat TAP 
tersebut. Berarti Ketetapan MPR/S haruslah tercantum dalam hierarki peraturan prundang-undangan untuk memperkuat Lembaga KPK dan UU Pemberantasan Tindak Pidana Korupsi yang menjalankan Amanat Ketetapan MPR No. IX/MPR/1998 dan Ketetapan MPR No.VIII/MPR/2001.

Dalam risalah sidang Perkara Nomor 86/ PUU-XI/2013 pengujian Pasal 7 Ayat (1) huruf b UU No. 12 Tahun 2011 terhadap UUD 1945, Hakim Konstitusi Maria Farida menyatakan untuk meluruskan paradigma para pemohon, Maria Farida Indarti menyatakan :

“...Anda benar juga ada Tap yang bisa sampai kiamat, kalau Anda melihat pada Tap Nomor XI Tahun 1998 tentang Penyelenggaraan Negeri yang Bersih Dan Bebas Korupsi, Kolusi, Dan Nepotisme, itu oleh Tap Nomor 1 Tahun 2003 dikatakan Tap ini masih tetap berlaku sampai terpenuhinya seluruh ketentuan di dalam Tap itu. Sekarang Anda mesti tanya, kapan Indonesia itu bebas korupsi? Kalau korupsinya itu sudah bebas, baru Tap itu tercabut, gitu kan. Nah, jadi ada Tap-Tap yang seperti itu. Tapi Tap itu kalau Anda cabut, Anda hilangkan, nanti KPK juga tercabut itu karena KPK itu sumbernya dari Tap Nomor XI Tahun 1998 ini. Nah, jadi kita bisa melihat di sini bahwa kita mengatakan ini boleh diuji atau tidak, ini dihilangkan atau tidak itu harus dilandaskan dengan teori-teori yang ada dan fakta yang ada. Karena Tap-Tap MPR itu juga kemudian ditindaklanjuti oleh undang-undang yang ada." 38

Berkaitan dengan pernyataan Hakim MK Maria Farida Indarti, penulis berpendapat pentingnya Ketetapan MPR/S tercantum dalam hierarki peraturan perundangundangan, karena akan berimplikasi pada kepastian hukum terhadap ketetapan

${ }^{38}$ Ibid. Hal. 6-7
MPR/S yang masih berlaku, ini berkaitan dengan teori yang bisa penulis analogikan dengan Teori Adolf Melker (Teori Dua Wajah Norma Hukum) yaitu, pertama : yang mana satu wajah ke atas yang artinya suatu norma hukum bersumber dan berdasar pada norma hukum di atasnya (berarti, norma hukum yang ada di bawah sudah pasti mengikuti perintah norma yang ada di atasnya, sehingga norma di bawah tidak boleh bertentangan dengan norma hukum yang lebih tinggi). Apabila bertentangan otomatis norma di bawah harus dicabut. Kemudian yang kedua : pada wajah lainnya ke bawah norma hukum tersebut sekaligus pula menjadi sumber bagi norma hukum yang berada di bawahnya. Sehingga penulis memahami apa yang dinyatakan Adolf Melker dalam teori dua wajah norma hukum tersebut, Ketika norma di atas dicabut maka sistem norma yang ada di bawah akan rusak atau tercabut pula. Sehingga ketika Ketetapan MPR/S ditiadakan dalam tatanan hierarki, otomatis UU yang berlaku yang berlandaskan pada Ketetapan MPR/S menjadi tidak jelas terhadap keberlakuannya (ketidak pastian hukum) apalagi Ketetapan MPR/S dicabut, maka UU yang berladaskan Ketetapan MPR/S harus dicabut pula bahkan imbasnya pada lembaga KPK yang harus dibubarkan. Maka dari itu, Ketetapan MPR/S harus tercantum dalam hierarki peraturan perundangundangan untuk memberikan jaminan kepastian hukum dalam sistem hukum Nasional Negara Republik Indonesia.

Suatu upaya untuk merevisi UU KPK menjadi program Legislasi nasional pada tahun 2016, namun dari pemberitaan di media-media, dalam draf rancangan UU KPK (RUU KPK) ternyata bertentangan dengan Ketetapan MPR No.VIII Tahun 2001 Tentang Rekomendasi Arah Kebijakan Pemberantasan Kebijakan KKN. Menurut Mantan Ketua Mahkamah Konstitusi (MK) Mahfud MD, Kamis, 8-10-2015 RUU inisiatif DPR RI ini sebagai “pembunuhan” 
terhadap KPK dipastikan tidak berlaku walau itu sudah disahkan. Persoalannya, kedudukan Ketetapan MPR RI lebih tinggi dibandingkan dengan UU. ${ }^{39}$

Ketetapan MPR Kedudukannya lebih tinggi dari UU yang dibuat DPR, itu diatur di dalam UU No. 12 Tahun 2011. apabila itu bertentangan dengan Ketetapan MPR, maka tidak boleh dilakukan. Pasalnya, tidak boleh teori yang menjadi doktrin, teori perjenjangan yang isinya sebuah peraturan yang lebih rendah tidak boleh bertentangan dengan peraturan yang lebih tinggi. ${ }^{40}$

Dalam padangannya, tentang draf RUU KPK Mahfud MD menyayangkan sikap DPR yang ingin mengebiri kewenangan $\mathrm{KPK}$, bahkan ingin "membunuh" lembaga yang menjadi harapan masyarakat dalam pemberatasan korupsi. Seyogyanya para Anggota Dewan membaca dulu Ketetapan MPR tentang pendirian KPK sebelum membuat draf UU yang akhirnya malah menimbulkan kontroversi. ${ }^{41}$

Dalam pemberitaan di media yang menuai pro dan kontra terhadap pembatasan kewenangan KPK, ada beberapa pasal dalam draf RUU KPK yang diajukan DPR memang sangat bertentangan dengan Ketetapan MPR No. VIII Tahun 2001. Pasal-pasal yang bertentangan antara lain soal pembatasan umur KPK hanya menjadi 12 Tahun dan membuat KPK yang lebih fokus ke pencegahan Korupsi. ${ }^{42}$

Menurut penulis dengan berbagai pemberitaan media tentang pembatasan kewenangan KPK, maka keberadaan Ketetapan MPR/S dalam hierarki harus tetap eksis atau tercantum di dalam UU dan berlaku sebagai peraturan perundang-undangan. Sehingga upaya-upaya pelemahan KPK tidak akan tercapai karena eksistensi dari

\footnotetext{
39 www.Parlementaria.com, RUU "Pembunuhan" KPK Bertentangan dengan TAP MPR, Tanggal, 20-112015 Pukul. 20.00 WITA

${ }^{40}$ Ibid.

${ }^{41}$ Ibid.

${ }^{42}$ bid.
}

Ketetapan MPR/S diakui di dalam hierarki peraturan perundang-undangan. Sehingga ketika ada UU yang bertentangan dengan Ketetapan MPR/S, maka UU tersebut harus dicabut.

Berkaitan dengan pentingnya Ketetapan MPR/S tercantum dalam hirarki, maka hal ini diperkuat oleh putusan MK No. 86/ PUU-XI/2013, Perihal pengujian UU No. 12 Tahun 2011 Tentang Pembentukan Peraturan Perundang-Undangan Terhadap UUD 1945. Dalam amar putusannya MK "menyatakan permohonan para pemohon tidak dapat diterima". ${ }^{43}$ Sehingga dengan dasar putusan tersebut kedudukan Ketetapan MPR/S tetap berada di bawah UUD, oleh karena itu penulis berpendapat bahwa keberadaan dari Ketetapan MPR/S dalam hierarki peraturan perudangundangan adalah sebagai bentuk untuk memberikan jaminan kepastian hukum terhadap Ketetapan MPR/S maupun beberapa UU yang berlandaskan pada Ketetapan MPR/S.

\section{B. Lembaga Yang Berwenang Menguji Ketetapan MPR/S}

\section{Sejarah pengujian Norma Hukum}

Gagasan pengujian norma hukum tersebut bukan merupakan hal yang baru dilakukan. Gagasan ini merupakan suatu gagasan yang telah lama diupayakan sejak priode kolonial atau sejak jaman prakemerdekaan. Dalam Praktik pengujian peraturan oleh para hakim dipengadilan sebenarnya telah ada sejak jaman kolonial, terutama masa pendudukan Belanda jauh sebelum Muhammad Yamin mengemukakan pemikiran itu dalam sidang pleno Badan Penyelidik Persiapan Kemerdekaan (BPUPK) 1945. Hanya saja dalam sejarah Ketatanegaraan lajim dikatakan bahwa ide pengujian peraturan itu muncul pertama

\footnotetext{
${ }^{43}$ Lihat Putusan MK No. 86/PUU-XI/2013 Perihal Pengujian Pasal 7 Ayat (1) huruf b UU No. 12 Tahun 2011 Tentang Pembentukan Peraturan Perundang-undangan terhadap UUD.
} 
kali saat yamin melontarkan dalam sidang BPUPK 1945 untuk menyiapkan rancangan hukum dasar untuk Negara Republik Indonesia yang merdeka dan berdaulat sebagaimana yang dijanjikan kemaharajaan Jepang pada $1944 .^{44}$

Praktik pengujian peraturan perundangundangan oleh badan peradilan pada masa kolonial berkaitan erat pada sistem hukum pada masa itu.

\section{Kewenangan Mahkamah Agung (MA) dan Mahkamah Konstitusi (MK) Dalam Menguji Norma Hu- kum}

Produk hukum yang dapat di uji oleh MA dan MK tentu berbeda lingkup kewenangan mengujinya sebagaimana yang tertuang di dalam UUD Tahun 1945 Pasal 24A Ayat (1) dan Pasal 24C Ayat (1). Kewenangan tersebut dapat dilihat sebagai berikut :

a. Kewenangan Mahkamah Agung (MA) Menguji Peraturan Perundang-Undangan di Bawah Undang-Undang Terhadap Undang-Undang

SesuaidenganlandasankonstitusiMA bewenang Untuk menguji noma hukum, Pasal 24A Ayat 1 yakni :

Ayat (1) Mahkamah Agung berwenang mengadili pada tingkat kasasi, menguji peraturan perundang-undangan di bawah undang-undang terhadap undang-undang, dan mempunyai wewenang lainnya yang diberikan oleh undang-undang. ${ }^{45}$

b. Kewenangan MahkamahKonstitusi(MK) Menguji UU Terhadap UUD 1945

MK berwenang menguji UU terhadap UUD seperti yang tertuang dalam UUD Tahun 1945 Pasal 24C yaitu :

${ }^{44}$ Periksa Sartono Kartodirdjo sebagaimana dikutip oleh Benny K. Harman, Mempertimbangkan Mahkamah Konstitusi, Sejarah Pemikiran Pengujian UU, Op. Cit. Hal 146-147.

${ }^{45}$ Undang-Undang Dasar Tahun 1945.
Ayat (1) Mahakamah Konstitusi berwenang mengadili pada tingkat pertama dan terakhir yang putusannya bersifat final untuk memutus sengketa sengketa kewenangan lembaga Negara yang kewenangannya diberikan oleh Undang-Undang Dasar, memutus pembaharuan partaipolitik, dan memutus perselisihan tentang hasil pemilihan umum.

Sebagaimana yang tertuang di dalam Pasal24C Ayat (1) jelas bahwa Mahkamah KonstitusidapatmengujiUndang-undang terhadap UUD 1945. Pengujian terhadap Ketetapan MPR/S bukan merupakan kewenangan dari MK, karena kedudukan dari Ketetapan MPR/S dalam hierarki berada di atas Undang-undang sehingga MK tidak dapat menguji Ketetapan MPR/S. Meskipun lembaga tersebut adalah lembaga pengawal konstitusi.

\section{Lembaga Yang Berwenang Menguji Ketetapan MPR/S}

Adanya sistem pengawalan yang dilakukan oleh lembaga Judicial, tentu tidak semua aturan dapat di uji oleh MK Maupun MA, Ini dapat dilihat dengan masih diakuinya Ketetapan MPR/S dalam hierarki peraturan perundang-undangan menurut UU No. 12 Tahun 2011. Persoalan tersebut yang menjadi topik inti dalam tulisan ini yakni terjadinya kekosongan norma hukum dalam pengujian Ketetapan MPR/S.

Berkaitan dengan tidak adanya lembaga yang menguji atau terjadinya kekosongan norma, namun di dalam praktiknya dikenal ada tiga macam norma hukum yang dapat di uji yakni :

1. Keputusan hukum/Norma hukum yang bersifat mengatur (regeling).

2. Keputusan hukum/Norma hukum yang bersifat penetapan (beschiking).

3. Keputusan Hukum/Norma hukum yang bersifat penghakiman (Vonnis). 
Ketiga bentuk norma hukum di atas samasama dapat di uji kebenarannya melalui mekanisme peradilan (justisial) ataupun mekanisme no-justisial. Jika pengujian itu dilakukan oleh lembaga peradilan, maka proses pengujian itu disebut sebagai judicial review. Namun jika pengujian itu bukan dilakukan oleh lembaga peradilan maka hal itu tidak dapat disebut sebagai judicial review. ${ }^{46}$

Sebelum dibentuknya MK, MPR berwenang menguji UU dan Ketetapan MPR/S terhadap UUD 1945. Kewenangan tersebut pernah diatur dalam Ketetapan MPR RI No. III/MPR/2000 Tentang Sumber Hukum dan Tata Urutan Peraturan Perundang-Undangan yakni :

Pasal 5

Ayat (1) Majelis Permusyawaratan Rakyat berwenang menguji Undang-Undang terhadapUndang-Undang Dasar, dan Ketetapan Majelis Permusyawaratan Rakyat.

Dalam TAP III/MPR/2000 dikatakan dalam Pasal 5 apabila ada undang-undang bertentangan dengan TAP MPR atau bertentangan dengan Undang-Undang Dasar, maka yang menguji MPR, Tapi apabila peraturan di bawah undang-undang bertentangan dengan undang-undang maka diujinya ke Mahkamah Agung. Nah, perubahan konstitusi kemudian mengatakan Apabila ada undang-undang bertentangan dengan Undang-Undang Dasar maka diuji ke Mahkamah Konstitusi. Apabila ada peraturan di bawah undang-undang bertentangan dengan undang-undang maka diuji ke Mahkamah Agung. Nah, sekarang apabila ada undang-undang bertentangan dengan TAP MPR ke mana? Kalau ada TAP MPR bertentangan dengan Undang-Undang Dasar ke mana? Tentunya itu tidak diadakan judicial review, pasti dengan political review. Siapa yang berhak? Kalau kita lihat pada

${ }^{46}$ Jimly Asshiddiqie, Hukum Acara Pengujian Undang-Undang, Op. Cit Hal. 1
Pasal itu, maka MPR-lah yang berhak.47 Sehingga penulis memahami bahwa pengujian Ketetapan MPR/S tidak dapat dilakukan oleh lembaga lain meskipun kedudukan antar lembaga sama derajatnya.

Pengujian terhadap peraturan perundang-undangan, di dalam teori hukum apabila ada peraturan perundangan sudah jelas mengatur undang-undang diuji oleh MK, kemudian di bawah undang-undang di uji oleh MA. Sekarang, kalau begitu TAP MPR itu memang tidak ada yang menguji (judicial review). Namun Kalau misalnya itu perkembangan politik dan konstelasi politik yang ada di MPR yang terdiri dari DPR dan DPD menganggap TAP MPR itu keliru, otomatis mereka yang membuat, mereka yang mencabut.48 Dengan demikian, ketika terjadinya kekosongan norma hukum yang mengatur tentang lembaga yang menguji ketetapan MPR/S, maka satu-satunya cara untuk menjawab persoalan tersebut adalah dengan mengajukan ke lembaga MPR, mengapa demikian? karena MPR adalah lembaga yang mengeluarkan produk hukum (ketetapan), berarti hanya MPR yang berwenang untuk menilai/menindak lanjuti apakah produk hukumnya itu masih layak untuk diberlakukan sebagai peraturan perundang-undangan atau tidak, dengan kata lain apakah bertentangan dengan UUD 1945 atau tidak. Jika bertentangan tentu Lembaga MPR dapat mencabut Ketetapannya yang bersifat regeling, karena secara teori norma yang ada di bawah tidak boleh bertentangan dengan norma yang

47 Periksa Risalah Sidang Mahkamah Konstitusi, Perkara No. 86/PUU-XI/2013. Di dalam naskah asli risalah sidang tersebut ditulis TAP 1 Tahun 2003 Pasal 4, Kemungkinan terjadi kesalahan dalam penulisan. Maksud dari penulisan tersebut sebenarnya Ketetapan MPR/III/2000 Pasal 5. Sehingga penulis merubah dengan mengacu pada TAP III/2000 karena di dalam TAP tersebut pada Pasal 5 mengatur kewenangan MPR menguji UU terhadap UUD dan Ketetapan MPR. Lihat juga pada penulisan tersebut penulis menggunakan Istilah Political Review, karena menurut penulis istilah political review lebih tepat karena MPR merupakan lembaga politik. Dalam naskah asli di tulis dengan Constitutional Review, Op. Cit. Hal. 4

${ }^{48}$ Ibid. Hal. 11 
lebih tinggi, apabila bertentangan tentu norma yang ada di bawah tersebut harus dicabut.

Untuk melihat bahwa, MPR berwenang untuk menilai Ketetapan MPR/S yang merupakan produk hukumnya sendiri, maka di dalam asas "Contrarius Actus" dalam hukum administrasi Negara adalah asas yang menyatakan badan atau pejabat tata usaha Negara yang menerbitkan keputusan tata usaha Negara dengan sendirinya juga berwenang untuk membatalkannya. Asas ini berlaku meskipun dalam keputusan tata usaha Negara tersebut tidak ada klausula pengaman yang lazimnya berbunyi : Apabila dikemudian hari ternyata ada kekeliruan atau kekhilafan maka keputusan ini akan ditinjau kembali. ${ }^{49}$

"Asas Contrarius Actus" ini berlaku tidak hanya untuk Keputusan Administrasi Negara, namun juga asas peraturan perundang-undangan. Sehingga yang berhak mencabut adalah pembentuknya itu sendiri dan tidak dapat dilakukan oleh peraturan atau lembaga yang lebih rendah. ${ }^{50}$ Dengan demikian apabila suatu Ketetapan dianggap bertentangan dengan UUD, maka pengajuannya harus ke lembaga MPR, Karena berdasarkan asas Contrarius Actus MPR memiliki kewenangan untuk menilai produk hukumnya sendiri.

Asas ini juga sering digunakan sebagai dasar putusan pengadilan tidak dapat mencabut dan membatalkan berlaku mengikatnya sebuah peraturan perundangundangan. Asas ini dahulu digunakan sebagai dasar oleh Mahkamah Agung dalam pengujian peraturan di bawah Undangundang (UU) dan hanya berwenang menyatakan tidak sah, sedangkan yang berwenang mencabut dan membatalkan adalah pembentuknya sendiri. ${ }^{51}$

49 http://www.miftakhulhuda.com/Contrarius Actus. di akses pada Tanggal 27 Desember 2015

${ }^{50}$ Ibid.

${ }^{51}$ Ibid.

138 IUS Kajian Hukum dan Keadilan
Berkaitan dengan peran asas hukum untuk menyelesaikan persoalan yang terjadi, maka penulis mengutip pendapat "Satjipto Raharjo" sebagaimana dikutip dari bukunya Sirajuddin, Fakthurohman \& Zulkarnain: Satjipto Raharjo menyatakan bahwa, asas hukum merupakan "jantungnya" peraturan hukum. Karena menurut Satjipto, asas hukum merupakan landasan yang paling luas bagi lahirnya suatu peraturan hukum. Ini berarti, peraturan-peraturan hukum itu pada akhirnya bisa dikembalikan pada asas-asas tersebut. Kecuali disebut landasan, asas hukum layak disebut sebagai alasan bagi lahirnya peraturan hukum, atau merupakan ratio legis dari peraturan hukum. Asas hukum tidak akan habis kekuatannya dengan melahirkan suatu peraturan hukum, melahirkan akan tetap saja ada akan melahirkan peraturanperaturan selanjutnya. ${ }^{52}$

Asas hukum sangat berperan penting untuk menjawab persoalan yang terjadi dalam penulisan ini. Oleh karena itu, hal lain yang dapat pula penulis berikan contoh yang berkaitan dengan adanya ketentuan yang mengatur bahwa MPR dapat menilai produk hukum yang dikeluarkannya maka, seperti yang tertuang dalam Pasal 3 Ayat (1) Undang-Undang Dasar 1945 yakni :

Ayat (1) Majelis Permusyawaratan Rakyat berwenang mengubah dan menetapkan Undang-Undang Dasar.

Ini artinya hanya MPR yang dapat menafsirkan UUD 1945, berarti MPR pun dapat pula menilai dan menafsirkan Ketetapan MPR/S, Karena keduanya samasama merupakan produk hukum dari MPR dan sama-sama berada di dalam tatanan hierarki, dimana di dalam UU No. 12 Tahun 2011 pada Pasal 7 Ayat (1) kedudukan UUD 1945 berada pada urutan pertama dan Ketetapan MPR/S berada pada urutan

\footnotetext{
${ }^{52}$ Sirajuddin, Fatkhurohman, et all. Legislatif Drafting Pelembagaan Metode Partisipatif Dalam Pembentukan Peraturan Perundang-Undangan, (Jakarta : Setara Press, 2015). Hal. 30
} 
kedua. Sehingga pengujian tersebut tidak dapat dilakukan oleh lembaga MK secara Judicial Review, melainkan hanya dengan menilai dan mencabut yang dapat dilakukan oleh Lembaga MPR yang merupakan Lembaga yang membuat produk Ketetapan tersebut yang bersifat regeling.

Seiring dengan tidak adanya lembaga Judicial yang mengujinya secara Judicial Review, maka di masa yang akan datang jika ada masyarakat yang ingin mengajukan pengujian Ketetapan MPR/S terhadap UUD 1945, tentu harus melalui Lembaga MPR. Akan tetapi, menurut penulis tidak dalam konteks menguji, melainkan Lembaga MPR hanya dapat menilai apakah Ketetapan MPR/S bertentangan dengan UUD 1945 atau tidak. Jika bertetangan maka MPR hanya dapat menilai Produk ketetapannya hingga mencabut produk yang bersifat regeling tersebut, karena saat ini pengujian Ketetapan MPR/S tidak diatur lagi. Sehingga prosesnya secara political review, oleh karena itu lembaga MPR memiliki alat kelengkapan yang terdiri dari pimpinan dan panitia ad hoc sebagaimana diatur dalam UU No. 17 Tahun 2014 Tentang MPR, DPR, DPD (MD3) yaitu: ${ }^{53}$

Pasal 14 Alat kelengkapan MPR terdiri atas :

a. Pimpinan ; dan

b. Panitia ad hoc MPR

Panitia Ad Hoc dapat melaksanakan tugasnya sebagaimana yang tertuang pada Pasal 22 yaitu dapat dilihat sebagai berikut $: 54$

Pasal 22

Ayat (1) Panitia ad hoc MPR bertugas :

a. Mempersiapkan bahan sidang MPR ; dan

b. Menyusun rancangan putusan MPR.

${ }^{53}$ Indonesia, UU No. 17 Tahun 2014 Tentang MPR, DPR, DPD (MD3).

${ }^{54}$ Ibid.
(2) Panitia ad hoc MPR melaporkan pelaksanaan tugas sebagaimana dimaksud Pada Ayat (1) dalam siding paripurna MPR.

(3) PanitiaadhocMPRdibubarkansetelah tugasnya selesai.

Pada alat kelengkapan MPR tersebut panitia Ad Hoc dapat mempersiapkan bahan sidang, sehingga prosesnya dapat dilakukan pada lembaga MPR sebagai lembaga satu-satunya yang dapat menilai dan mempertimbangkan Ketetapan MPR/S yang bertentangan dengan UUD 1945 atau tidak, karena Ketetapan MPR/S merupakan produk hukumnya sendiri.

\section{SIMPULAN}

Berdasarkan apa yang telah diuraikan dalam tulisan ini tentang eksistensi Ketetapan MPR/S dalam hierarki peraturan perundang-undangan di Indonesia, maka dapat ditarik kesimpulan sebagai berikut yaitu :

1. Ketetapan MPR/S dikeluarkan dan dicantumkan kembali dalam hierarki peraturan perundang-undangan di Indonesia yaitu :

- Dikeluarkannya Ketetapan MPR/S pada tatanan hierarki peraturan perundang-undangan menurut UU No. 10 Tahun 2004 Tentang Pembentukan Peraturan Perundangundangan, pertimbangannya adalah untukmenjagakonsistensipenyebutan peraturan perundang-undangan yang bersifat mengatur digunakan istilah "Peraturan". Hal ini dimaksudkan agar tidaklagiterjadiatautimbulpertanyaan mengenai istilah "Keputusan" yang bersifat mengatur ataupun yang bersifatpenetapan.SehinggaKetetapan MPR/S tidak tercantum dalam hierarki Peraturan Perundang-undangan. 
- Dengan dicantumkan kembali Ketetapan MPR/S dalam hierarki peraturan perundang-undangan dalam UU No. 12 Tahun 2011 Tentang Pembentukan Peraturan Perundangundangan dengan pertimbangan untuk memberikan jaminan kepastian hukum terhadap Ketetapan MPR/S yang bersifat mengatur (regeling), dan sebagai wujud untuk menguatkan UU yang berlandaskan pada Ketetapan $\mathrm{MPR} / \mathrm{S}$.

Lembaga yang berwenang menguji Ketetapan MPR/S di Indonesia pernah diatur pada Pasal 5 Ketetapan MPR No. III/MPR/2000 Tentang Sumber Hukum dan Tata Urutan Peraturan Perundangundangan, dimana MPR berwenang untuk menguji Undang-undang terhadap UndangUndang Dasar dan Ketetapan MPR, tetapi Ketetapan MPR ini sudah dicabut berdasarkan Ketetapan MPR RI No. I/ MPR/2003 Tentang Peninjauan Terhadap Materi dan Status Hukum Ketetapan MPRS dan MPR RI Tahun 1960 sampai dengan Tahun 2002, sehingga terjadi kekosongan norma terhadap lembaga yang menguji Ketetapan MPR/S. Namun berdasarkan asas "contrarius actus", MPR berwenang untuk menilai dan mencabut Ketetapan MPR/S yang merupakan produk hukumnya sendiri.

\section{DAFTAR PUSTAKA}

\section{Buku-buku}

Asshiddiqie Jimly, 2006 Hukum Acara Pengujian Undang-Undang, (Jakarta : Konstitusi Press).

Asshiddiqie Jimly, 2014 Perihal UndangUndang, Cetakan. 3 (Jakarta :Raja Grafindo Persada).

Huda Ni'matul, 2014 Hukum Tata Negara Indonesia. Cet Ke 9 (Jakarta : Raja Grafindo Persada).

Hady Nuruddin, 2010 Teori Konstitusi dan Negara Demokrasi Paham
Konstitusionalisme Demokrasi

Pasca Amandemen UUD 1945, Cet.

1 (Malang : Setara Press).

K. Harman Benny, 2013 Mempertimbangkan Mahkamah Konstitusi, Sejarah Pemikiran Pengujian UU Terhadap UUD, Cet. Ke 1 (Perpustakaan Populer Gramedia).

Purnama I Ketut Adi, 2011 Transparansi Penyidikan dalam Kerangka Sistem Peradilan Pidana Untuk Membangun Kepercayaan Masyarakat Terhadap Polri, Disertasi, Universitas Katolik Parahyangan.

Ranggawidjaja Rosjidi, 1998 Pengantar Ilmu Perundang-Undangan Indonesia, Cetakan Ke. 1. (Bandung : Mandar Maju).

Samsudin Aziz, 2013 Proses \& Teknik Penyusunan Undang-Undang, Edisi Kedua Cetakan Ke. 1(Jakarta :Sinar Grafika).

Sirajuddin, Fatkhurohman, dan Zulkarnain, 2015 Legislatif Draftin, Pelembagaan Metode Parsitipatif Dalam Pembentukan Pembentukan Peraturan Perundang-Undangan, (Malang : Setara Press).

Zoelva Hamdan, 2011 Pemakzulan Presiden di Indonesia, Cet. 1 (Jakarta : Sinar Grafika).

\section{Jurnal}

Agustiwi Asri, Keberadaan Lembaga Negara Pasca Amandemen UndangUndang Dasar 1945 di Indonesia, Jurnal Rechstaat, Vol. 8 No. 1 (Maret 2014).

Mukhlis, "Kewenangan Lembaga-lembaga Negara Dalam Memutus dan Menafsirkan UUD Setelah Amandemen Keempat UndangUndang Dasar 1945", Jurnal Syiar Hukum, Vol. 13 No. 1 (Maret 2011). 
M. Saoki Oktava|Eksistensi Ketetapan MPR/S Dalam Hierarki Peraturan Perundang-Undangan

Solikhah Nur Amin, Problematika Hukum Undang-Undang No. 42 Tahun 1999 Tentang Jaminan Fidusia Terkait Dengan Peraturan Menteri Keuangan Republik Indonesia No. 130/MPK. 010/2012. Jurnal Repertorium, ISSN : 2355-2646, Edisi 3 Januari-Juni 2015

Sri Nur Hari Susanto, "Pergeseran Kekuasaan Lembaga Negara Pasca Amandemen UUD 1994", Jurnal Masalah-Masalah Hukum, Vol. 43 No. 2 (April 2014).

Warsito, "Implikasi Amandemen UUD 1945 Terhadap Kedudukan, Fungsi, Tugas dan Wewenang Majelis Permusyawaratan Rakyat (MPR)" Supremasi Hukum, Vol. 11 No. 1 (Januari 2015).

Arifin Hoesein Zainal, "Pembentukan Hukum Dalam Perspektif Pembaharuan Hukum", Jurnal Rechtsvinding, Media pembaharuan Hukum, Vol. 1 No. 3 (Desember 2012).

\section{Internet-internet}

www.Parlementaria.com,

RUU

"Pembunuhan" KPK Bertentangan dengan TAP MPR.

http://www.miftakhulhuda.com/ Contrarius Actus.

http://www.herdi.web.id/kedudukan-tapmpr-dalam-sistem-perundangundangan-indonesia.

www.hukumonline.com, Hierarki Peraturan Perundang-undangan Berubah, (Jum'at 22 Juli 2011).

Mahkamah Konstitusi Republik Indonesia, Risalah Sidang, Perkara No. 86/PUU-XI/2013, Perihal Pengujian Pasal 7 Ayat (1) hurufb Undang-Undang No. 12 Tahun 2011 Tentang Pembentukan Peraturan Perundang-
Undangana Terhadap UndangUndang Dasar Negara Republik Indonesia Tahun 1945.

Putusan MK No. 86/PUU-XI/2013 Perihal Pengujian Pasal 7 Ayat (1) huruf b UU No. 12 Tahun 2011 Tentang Pembentukan Peraturan Perundang-undangan terhadap Undang-Undang Dasar Negara Republik Indonesia Tahun 1945.

www.dpr.go.id, Layanan Informasi Publik, Pejabat Pengelola Informasi dan Dokumentasi (PPID) DPR-RI,

Proses Pembahasan, Rancangan Undang-Undang Republik

Indonesia Tentang Pembentukan

Peraturan Perundang-Undangan,

Biro Persidangan Dewan

Perwakilan Rakyat Republik

Indonesia 2004, Sambutan

Pemerintah atas Persetujuan

Rancangan Undang-Undangan

Tentang pembentukan Peraturan

Perundang-undangan dalam

rapat paripurna terbuka Dewan

Perwakilan Rakyat Republik

Indonesia.

www.dpr.go.id, Layanan Informasi Publik, Pejabat Pengelola Informasi dan Dokumentasi (PPID) Sekretariat Jendral DPR-RI, Risalah Rapat Panitia Khusus Rancangan UndangUndang Tentang Pembentukan Pertaturan Perundang-Undangan, Jenis Rapat : Raker I Tanggal : 13 Desember 2010.

www.dpr.go.id, Layanan Informasi Publik, Pejabat Pengelola Informasi dan Dokumentasi (PPID) Sekretariat Jendral DPR RI, Risalah Rapat Panitia Khusus Rancangan UndangUndang Tentang Pembentukan 
Peraturan Perundang-Undangan, Jenis Rapat : Raker IV Tanggal 2 Maret 2011.

\section{Peraturan-peraturan}

Indonesia, Undang-Undang Dasar 1945, 2014 dilengkapi dengan Kabinet Kerja Periode 2014-2019, Cet 1 (Yogyakarta : Pustaka Baru Press).

Indonesia, Ketetapan Majelis Permusyawaratan Rakyat Sementara Republik Indonesia Nomor. III/MPR/2000 Tentang Sumber Hukum dan Tata Urutan Peraturan Perundang-Undangan.

Indonesia, Ketetapan MPR RI No. VIII/2001 Tentang Rekomendasi Arah Kebijakan Pemberantasan dan Pencegahan Korupsi, Kolusi dan Nepotisme.

Indonesia, Ketetapan Majelis Permusyawaratan Rakyat Sementara Re- publik Indonesia Nomor. III/ MPR/2000 Tentang Sumber Hukum dan Tata Urutan Peraturan Perundang-Undangan.

Indonsia Majelis Permusyawaratan Rakyat Indonesia, Ketetapan MPR RI No. I/MPR/2003, Cet. Ke 10, Sekretariat Jendral MPR RI 2011

Indonesia, UU No. 17 Tahun 2014 Tentang MPR, DPR, DPD (MD3). LN No. 182 Tahun 2014 TLN No.5568

Indonesia, Undang-Undang No. 12 Tahun 2011 Tentang Pembentukan Peraturan Perundang-undangan. LN No. 82 Tahun 2011, TLN No. 5234

Indonesia, Undang-undang No. 10 Tahun 2004 Tentang Pembentukan Peraturan Perundang-undangan. LN No. 53 Tahun 2004, TLN No. 4389 . 